\title{
MAKNA DAN NILAI BUKA LUWUR SUNAN KUDUS (Sumbangan Pemikiran Mewujudkan Visi Kampus Kebudayaan)
}

\author{
Erik Aditia Ismaya ${ }^{1}$, Irfai Fathurohman ${ }^{2}$, dan Deka Setiawan ${ }^{3}$ \\ email: erik.aditia@umk.ac.id; irfai.fathurohman@umk.ac.id; deka.setiawan@umk.ac.id \\ ${ }^{1}$ Program Studi Pendidikan Guru Sekolah Dasar, Universitas Muria Kudus \\ ${ }^{2}$ Program Studi Pendidikan Bahasa dan Sastra Indonesia, Universitas Muria Kudus \\ ${ }^{3}$ Program Studi Pendidikan Guru Sekolah Dasar, Universitas Muria Kudus
}

\begin{abstract}
The purpose of this research is to know the meaning and value in Buka Luwur Sunan Kudus and to design the implementation model of meaning and value in Buka Luwur Sunan Kudus to realize the vision of "Kampus Kebudayaan". The results showed that Buka Luwur was held in order to commemorate the haul of Sunan Kudus. Haul is a ceremony to commemorate the death of a scholar or a meritorious figure. Buka Luwur Sunan Kudus contains the meaning and symbol of noble values and high educational value that is: a sense of tolerance to others, mutual help-help and appreciate, train and get used to charity, always closer to God, able to nurture noble character and curbing negative actions and reminding people to do good deeds for the provision of life after death. The meaning and value of Buka Luwur are very relevant to Universitas Muria Kudus which has the vision of being a " "Kampus Kebudayaan" "with the characteristic of "Smart and Fluent" graduates. Through the Tri Darma of the university, the meaning and value of Buka Luwur can be implemented in every darma in an effort to realize the vision of "Kampus Kebudayaan".
\end{abstract}

Keywords: meaning, value, buka luwur, kampus kebudayaan

\begin{abstract}
Abstrak
Tujuan penelitian ini yaitu mengetahui makna dan nilai dalam Buka Luwur Sunan Kudus serta merancang model implementasi makna dan nilai dalam Buka Luwur Sunan Kudus untuk mewujudkan visi Kampus Kebudayaan. Hasil penelitian menunjukkan bahwa Buka Luwur dilaksanakan dalam rangka memperingati haul Sunan Kudus. Haul adalah upacara untuk memperingati wafat seorang ulama atau tokoh yang berjasa. Buka Luwur Kudus Sunan mengandung makna dan simbol nilai-nilai luhur dan nilai edukatif yang tinggi yaitu: rasa toleransi kepada sesama, rasa saling tolong-menolong dan menghargai, melatih dan membiasakan diri bersedekah, selalu mendekatkan diri kepada Tuhan, mampu membina budi pekerti luhur dan mengekang perbuatan negatif serta mengingatkan agar orang-orang supaya beramal-ibadah yang baik untuk bekal kehidupan sesudah mati. Makna dan nilai Buka Luwur yang tergali sangat relevan dengan Universitas Muria Kudus yang memiliki visi menjadi "Kampus Kebudayaan" dengan ciri khas lulusan "Cerdas dan Santun". Melalui Tri Darma perguruan maka makna dan nilai Buka Luwur dapat diimplementasikan dalam setiap darma dalam upaya mewujudkan visi "Kampus Kebudayaan".
\end{abstract}

Kata kunci: makna, nilai, buka luwur, universitas kebudayaan

\section{PENDAHULUAN}

Kudus merupakan salah satu pusat syiar Islam pada era Kerajaan Demak. Pada jaman dahulu, Kudus dikenal sebagai daerah yang sulit

\section{Jurnal Kredo}

Vol. 1 No. 1 Oktober 2017 ditaklukkan oleh Islam dan atas kesepakatan para Wali maka diutuslah Sunan Kudus untuk menyebarkan dan mensyiarkan Islam di Kudus. Sunan Kudus yang berdakwah dengan jalan 
kebijaksanaan pada perjalanan dakwah dan syiar-nya mendapat simpati dari masyarakat Kudus. Berbondong-bondonglah masyarakat Kudus memeluk Islam yang sampai hari ini terus bertambah pemeluknya.

Kudus merupakan sebuah kota yang terkenal julukannya sebagai Kota Santri. Berdasarkan data Kantor Kementerian Agama Kabupaten Kudus tahun 2015, terdapat 68 pondok pesantren dengan jumlah santri sebanyak 13.510 orang serta 92 Kyai dan 874 Ustadz (Kudus Dalam Angka 2016: 183). Banyaknya jumlah pesantren serta santri yang belajar, membuktikan bahwa sebutan Kota Santri layak disandang oleh Kota Kudus. Sebutan Kota Santri bukan sembarangan diberikan kepada Kudus, akan tetapi ini dibuktikan dengan sikap dan perilaku masyarakat Kudus itu sendiri.

Santri dalam pengertian umum adalah sebutan untuk seorang yang mempelajari ilmu agama. Geertz (1989) berpendapat bahwa kata santri mempunyai arti luas dan sempit. Dalam arti sempit santri adalah "seorang murid satu sekolah agama yang disebut pondok atau pesantren". Kata Pesantren itu sendiri diambil dari akar kata santri yang berarti "tempat untuk para santri". Dalam arti luas dan umum santri adalah bagian penduduk Jawa yang memeluk Islam secara benar-benarbersembahyang, pergi ke mesjid pada hari Jum'at dan seterusnya. Berdasarkan data Kantor Kementerian Agama Kabupaten Kudus tahun 2012, komposisi pemeluk agama di Kudus yaitu Islam 813.924 orang, Kristen 11.458 orang, Katholik 4.576 orang, Hindu 22 orang, Budha 1.016 orang dan kepercayaan lain 307 orang (Kudus Dalam Angka 2016: 184).

Kudus sebagai Kota Santri merupakan simbol dari masyarakat yang religius. Religiusitas masyarakat Kudus tercermin dari sikap dan perilaku sehari-hari yang selalu menjunjung tinggi kerukunan, ketenangan, ketentraman dan kedamaian. Religiusitas masyarakat Kudus tidak dapat dilepaskan dari peran Sunan Kudus atau Raden Ja'far Shodiq sebagai leluhur masyarakat Kudus.

Sunan Kudus sebagai leluhur masyarakat Kudus mewariskan sebuah ajaran yang dikenal dengan falsafah GUSJIGANG, yakni baGUS, ngaJI, dan berdaGANG sebagai ruh yang harus dijaga dalam rangka meningkatkan kualitas pribadi serta ekonomi sebagai bekal hidup. Ismaya (2013) mencatat bahwa Sunan Kudus merupakan sosok yang sangat pluralis atau menghargai keberbedaan dan keragaman yang ada. Misalnya, anjuran Sunan Kudus melarang menyembelih sapi, karena sapi merupakan hewan yang dimuliakan oleh penganut ajaran Hindu. Bangunan Menara Kudus yang mirip dengan candi juga bisa menjadi salah satu penghargaan lain Sunan Kudus terhadap masyarakat yang waktu itu banyak memeluk Hindu-Budha.

Sunan Kudus merupakan seorang yang moderat, maksudnya selalu menghindarkan perilaku atau pengungkapan yang ekstrem; berkecenderungan ke arah dimensi atau jalan tengah: pandangannya cukup --, mau mempertimbangkan pandangan pihak lain (Kamus Bahasa Indonesia 2008: 964). Sunan Kudus merupakan seorang yang 
egaliter dan bijaksana. Egaliter artinya bersifat sama; sederajat dan bijaksana adalah kepandaian menggunakan akal budinya (pengalaman dan pengetahuannya); kecakapan bertindak apabila menghadapi kesulitan dsb; pimpinan dan cara bertindak (mengenai pemerintahan, partai, dsb) (Kamus Bahasa Indonesia 2008: 199).

Sosok Sunan Kudus sebagai leluhur yang mengajarkan toleransi, penghargaan dan kebijaksanaan membuat suasana kerukunan hidup beragama dan kepercayaan terhadap Tuhan Yang Maha Esa sangat dijaga dan didambakan masyarakat Kota Kudus. Beragam tempat peribadatan, merupakan salah satu bukti kerukunan agama diantara umat beragama. Pada tahun 2015 sarana peribadatan yang ada yaitu, masjid 663 buah, mushola/langgar 2.013 buah, gereja Kristen 22 buah, gereja Katholik 4 buah, Vihara 12 buah dan Klenteng 3 buah (Kudus Dalam Angka 2016: 182).

Dinamika dalam kehidupan membuat suasana kerukunan hidup beragama di Kudus pernah tercoreng oleh peristiwa

Kerusuhan bernuansa suku, agama, ras dan antar golongan (SARA). Adapun peristiwa itu terjadi pada tahun 1918. Peristiwa huru-hara yang terjadi antara kaum muslimin dan orang-orang tionghoa ini tepatnya terjadi pada tanggal 31 Oktober-01 November 1918. Peristiwa ini dilatar belakangi oleh sebuah kejadian yang dianggap menghina dan melukai hati kaum muslimin.

Salam (1986: 18) memaparkan pada waktu itu umat muslim

46 | Jurnal Kredo Vol. 1 No. 1 Oktober 2017 memuntahkan segala kemarahannya serta menunjukkan sikap keperwiraannya dalam melawan golongan tionghoa, karena waktu itu orang-orang tionghoa membuat leang-leong untuk membasmi wabah influenza dan membuat orangorangan yang berpakaian haji serta membawa ledek (pelacur) berciumciuman serta berjalan melalui depan Masjid Menara Kudus. Hal ini dianggap sebagai suatu tantangan yang perlu dijawab. Akhirnya atas anjuran Kyai R. Asnawi, dikerahkan sejumlah besar umat Islam di Kudus untuk melakukan perlawanan total melawan golongan tionghoa.

Religiusitas masyarakat Kudus dalam kehidupan sehari-hari turut membentuk budaya masyarakat Kudus. Rasa hormat masyarakat Kudus kepada Raden Ja'far Shodiq sangatlah besar dan sebagai wujud penghormatannya masyarakat Kudus rajin ke makam Sunan Kudus. Kebiasaan berziarah masyarakat Kudus ke makam Sunan Kudus ternyata sudah menjadi budaya bagi masyarakat Kudus. Setiap hari kompleks makam Sunan Kudus selalu ramai dikunjungi para peziarah dari Kudus maupun luar Kudus. Peziarah akan semakin banyak ketika malam Jum'at tiba, terlebih lagi pada saat bulan Suro atau Muharram. Kompleks Masjid, Makam dan Menara Kudus menjadi sangat ramai karena mulai tanggal 1 bulan Suro sampai tanggal 10 Suro ada rangkaian acara Buka Luwur Sunan Kudus.

Buka Luwur merupakan salah satu budaya masyarakat Kudus yang dijaga keberadaannya serta diwariskan turun-temurun untuk menghormati Sunan Kudus sebagai leluhur. Rangkaian acara Buka 
Luwur dilaksanakan pada bulan Suro, mulai tanggal 1 Suro dan mencapai puncaknya pada tanggal 10 Suro merupakan budaya yang penuh makna dan nilai jika digali secara mendalam serta menyeluruh.

Buka Luwur sebagai sebuah budaya telah menarik perhatian beberapa peneliti, antara lain Penelitian Ni'mah (2007) yang membahas pengelolaan dana umat untuk pengembangan dakwah Islam melalui tradiri Buka Luwur di Makam Sunan Kudus. Pengelolaan dana umat untuk pengembangan dakwah Islam dapat tersalurkan dan tertata rapi dengan manajemen yang baik oleh panitia Buka Luwur.

Kedua penelitian Ismaya (2008) yang mengungkap bahwa Upacara Buka Luwur Makam Sunan Kudus memiliki nilai yang sangat tinggi yaitu meneladani nilai-nilai dari perjuangan para Wali khususnya Sunan Kudus dalam hidup bermasyarakat. Adapun dalam Upacara Buka Luwur Makam Sunan Kudus terkandung makna dan nilai luhur antara lain: rasa toleransi yang tinggi kepada sesama, rasa saling tolong-menolong dan menghargai, membiasakan diri untuk bersedekah, selalu mendekatkan diri kepada Tuhan YME, mampu membina budi pekerti luhur, mengekang perbuatan tercela, serta mengingatkan supaya senantiasa beramal ibadah sebagai bekal kehidupan sesudah mati.

Ketiga penelitian Fuadi (2012) yang menunjukkan bahwa resepsi masyarakat Kabupaten Kudus atas Upacara Buka Luwur Makam Sunan Kudus sangat baik dan antusias. Kemampuan itu dimiliki karena lingkungan yang mendukung serta faktor usia, latar belakang pendidikan dan agama masyarakat Kabupaten Kudus.

Keempat penelitian Argarini (2015) yang mengungkap bahwa pihak panitia dan masyarakat Desa Kauman memaknai nasi jangkrik sebagai sedekah dari Sunan Kudus yang pahalanya ditujukan kepada Beliau serta sebagai media penyampai pesan untuk peduli terhadap sesama umat manusia.. Pada sisi penerimaan pesan di pihak komunikan terdapat interpretasi bahwa apa-apa yang berhubungan dengan Sunan Kudus dapat membawa berkah sehingga masyarakat berdesak-desakan untuk mendapatkannya.

Kelima penelitian Nuha (2016) menunjukkan bahwa tradisi Buka Luwur mengandung nilai-nilai keteladanan sehingga perlu dilembagakan dan diwariskan kepada generasi muda. Buka Luwur juga berfungsi mempersatukan kelompok sosial, perekat masyarakat, memperkuat keyakinan terhadap yang gaib serta menjaga keseimbangan dan keselarasan hidup dari masa ke masa.

Universitas Muria Kudus (UMK) merupakan salah satu Perguruan Tinggi di Kudus yang lahir dan terinspirasi oleh sosok Sunan Kudus dan Sunan Muria. Universitas Muria Kudus yang mempunyai visi menjadi "Kampus Kebudayaan" dengan ciri khas lulusan "Cerdas dan Santun" menjadikan Universitas Muria Kudus wajib untuk menggali budaya masyarakat Kudus sebagai obyek tri darma perguruan tinggi dalam rangka mewujudkan visi universitas serta ciri khas lulusan. 
Buka Luwur sebagai salah budaya masyarakat Kudus dan diduga mengandung makna serta nilai yang berguna, khusunya bagi Universitas Muria Kudus sebagai bahan kajian mewujudkan "Kampus Kebudayaan”, ternyata belum digali, ditafsirkan dan diimplementasikan dengan mendalam serta menyeluruh sehingga perlu dilakukan penelitian lebih lanjut. Oleh karena itu, peneliti bermaksud mengggali, menafsirkan serta mengimplementasikan makna dan nilai dalam Buka Luwur dengan riset berjudul: Makna dan Nilai Dalam Buka Luwur (Sumbangan Pemikiran Mewujudkan Kampus Kebudayaan).

Buka Luwur sebagai salah satu budaya masyarakat Kudus, diduga belum dipahami oleh semua masyarakat Kudus. Terlebih lagi, makna dan nilai yang terkandung dalam Buka Luwur. Oleh karena itu, pertanyaan utama dalam penelitian ini yaitu "mengapa masyarakat Kudus melaksanakan Buka Luwur?". Pertanyaan utama diturunkan menjadi beberapa pertanyaan penelitian sebagai berikut 1) bagaimana makna dan nilai dalam Buka Luwur Sunan Kudus? 2) Bagaimana implementasi makna dan nilai dalam Buka Luwur Sunan Kudus untuk mewujudkan visi Kampus Kebudayaan?

\section{METODE PENELITIAN}

Penelitian ini menggunakan pendekatan kualitatif dengan jenis penelitian kasus atau studi lapangan. Lokasi penelitian yaitu sekitar Masjid "Al Aqsho" (Menara Kudus) dan Makam Sunan Kudus yang

48 | Jurnal Kredo Vol. 1 No. 1 Oktober 2017 berada dalam satu kompleks tempat berlangsungnya Buka Luwur.

Data utama diperoleh langsung peneliti melalui wawancara dengan informan yaitu pengurus Yayasan Masjid, Menara dan Makam Sunan Kudus; pemerhati budaya Kudus dan warga Kudus dari berbagai kalangan dengan kategori tertentu. Data sekunder yaitu semua dokumen yang memuat informasi tentang buka luwur dan telah dibukukan, sehingga peneliti dapat mengutip data untuk keperluan tertentu.

Dalam penelitian ini, wawancara ditujukan kepada Bapak Haji Nadjib Hasan Ketua Yayasan (YM3SK); Bapak Haji Nur Riza Bapak Rafiqul Hidayat, Kepala Desa Kauman; Bapak Sujak; Bapak Bakri; Bapak Shobari; Bapak Ali; Bapak Jamaah; Bapak Haji Isman dan masyarakat sekitar (Mas Adi, Pak Bambang Setyadi, Mbak Nina, Mbak Yunis dan Mbak Sari) yang mengikuti rangkaian Buka Luwur ini.

Validitas data dalam penelitian yaitu teknik triangulasi sumber. Analisis data dilakukan melalui analisis induktif-deskriptifverivikatif. Analisis data dalam penelitian dilakukan pada saat pengumpulan data berlangsung, dan setelah selesai pengumpulan data dalam periode tertentu. Dalam penelitian ini, digunakan model analisis data model Creswell.

\section{HASIL DAN PEMBAHASAN}

Bagi masyarakat Kudus, Sunan Kudus merupakan sosok yang sangat dihormati dan dihargai, beliau telah berhasil membawa masyarakat Kudus menuju ke jalan kebenaran 
dan abad pencerahan. Sunan Kudus berhasil membentuk pola kehidupan masyarakat Kudus yang religius, aman, tentram dan damai. Sunan Kudus bersama Kyai Haji Telingsing sebagai leluhur atau leluwur masyarakat Kudus merupakan founding fathers kota Kudus.

Masyarakat Kudus sangat menghormati Sunan Kudus, tiap malam jum'at masyarakat Kudus menyempatkan diri berziarah ke makam Sunan Kudus dan tiap tahun Masyarakat Kudus juga mengadakan Buka Luwur Sunan Kudus sebagai wujud kecintaan dan penghormatan kepada Sunan Kudus. Lalu timbullah pertanyaan mengapa masyarakat Kudus mengadakan Buka Luwur Sunan Kudus? Untuk menjawab pertayaan ini, peneliti memperoleh keterangan langsung dari Bapak Haji Nur Riza Juru Kunci Makam Sunan Kudus

Buka Luwur dilaksanakan dalam rangka memperingati haul Sunan Kudus dimana tanggal wafat Sunan Kudus tidak diketahui secara pasti, sehingga berdasarkan kesepakan para ulama diadakan Buka Luwur dan dipilih tanggal 10 suro untuk melaksanakannya. Haul adalah upacara untuk memperingati wafat seorang ulama atau tokoh yang berjasa. Buka Luwur adalah nama lain dari haul Sunan Kudus karena dikhawatirkan kalau disebut haul Sunan Kudus maka masyarakat Kudus akan menganggap bahwa tanggal 10 suro merupakan tanggal wafatnya Sunan Kudus (Wawancara dengan Bapak Haji Nur Riza Juru Kunci Makam Sunan Kudus. Selasa 7 Maret 2017)

Buka Luwur Sunan Kudus merupakan sebuah bentuk upacara adat untuk menghubungi leluhur yang dilakukan oleh orang-orang yang masih hidup kepada leluhurnya yaitu Sunan Kudus. Sunan Kudus merupakan seorang yang memiliki sifat-sifat luhur pada masa hidupnya, dan setelah meninggal Sunan Kudus masih selalu dihubungi oleh mereka yang masih hidup dengan melakukan ziarah dan Buka Luwur.

Prosesi Buka Luwur Sunan Kudus merupakan sebuah rentetan acara yang sangat panjang. Drs. H. Em. Nadjib Hasan, Ketua Yayasan Masjid Menara dan Makam Sunan Kudus (YM3SK) menuturkan

Tradisi Buka Luwur akan berlangsung selama 10 hari semenjak malam 1 suro hingga tanggal 10 suro. Dalam sepuluh hari tersebut, akan diisi rangkaian tradisi yang ditandai dengan pelepasan Luwur (kelambu) makam, dan dilanjutkan dengan tradisi lainnya diantaranya: Munadharah Masail Diniyah, Doa Rasul dan Terbangan, penyembelihan hewan shadaqoh, pembagian bubur asyura, serta santunan anak yatim, pembagian berkat umum, dan hingga puncak acara yakni pemasangan kembali Luwur makam (Wawancara dengan Bapak Haji Nadjib Hasan, Ketua Yayasan Masjid, Menara dan Makam Sunan Kudus. Kamis 2 Maret 2017).

Dalam setiap acara Buka Luwur peneliti menemukan beberapa hal yang menarik serta unik, untuk itu berikut disampaikan beberapa temuan penelitian yang dimaksud

1. Pencucian Pusaka Sunan Kudus

Rangkaian acara Buka Luwur Sunan Kudus sebetulnya sudah dimulai sejak bulan besar atau Idul Adha dengan acara penjamasan 
pusaka Sunan Kudus yang bernama Ciptoko atau Cintoko. Setiap pencucian pusaka, cuaca pasti timbreng dan tidak diketahui secara pasti apakah karena keampuhan pusaka Sunan Kudus sehingga cuaca menjadi timbreng atau memang kebetulan saja, setiap ada pencucian pusaka cuacanya memang timbreng. Cuaca timbreng adalah dimana cuaca tidak panas dan tidak hujan, matahari juga tertutup oleh awan mendung. Biasanya air bekas untuk mencuci keris tersebut yang dalam bahasa jawa disebut dengan "kolo" diperebutkan masyarakat yang memiliki keris untuk mencuci kerisnya, karena mengharap "berkah" dari Sunan Kudus.

Keris Ciptoko atau Cintoko merupakan senjata andalan Sunan Kudus dalam berperang, karena posisi beliau sebagai Panglima Perang Kerajaan Demak. Keris Ciptoko atau Cintoko merupakan simbol kepandaian, keuletan dan ketangkasan Sunan Kudus untuk menghadapi segala tantangan hidup sehingga beliau mendapat julukan Waliyul Ilmi. Pusaka yang dimiliki Sunan Kudus bukanlah pusaka yang sembarangan. Pusaka ini tentunya memiliki daya magis, spritual dan sakral. Pusaka Sunan Kudus yang berupa keris Ciptoko atau Cintoko mempunyai daya pengaruh dan daya kekuatan besar untuk mempengaruhi pemiliknya dan warga masyarakat.

Peneliti dapat mengambil sebuah simpulan bahwa Keris Ciptoko atau Cintoko ini memiliki makna dan nilai yang sangat tinggi. Keris Cintoko merupakan simbol dari kebesaran dan kekuasaan Tuhan yang menciptakan alam semesta. Dari sebuah keris yang merupakan sebagian kecil dari kekuatan dan

50 | Jurnal Kredo

Vol. 1 No. 1 Oktober 2017 kekuasaan Tuhan, bisa merubah cuaca dan membawa pengaruh yang besar bagi kehidupan umat manusia lalu bagaimana dengan kekuatan dan kekuasaan Tuhan yang Maha Dahsyat. Tentunya akan lebih mengesankan dan menghebohkan lagi, namun kita hanya manusia biasa yang tidak akan tahu seberapa hebat kekuatan Tuhan.

\section{Pengajian Malam 1 Suro}

Tiap kali memasuki bulan Muharam atau bulan Suro maka sudah menjadi tradisi bagi kaum muslim untuk melakukan doa yang disebut doa awal dan akhir tahun. Doa itu dilakukan untuk merevitalisasi kadar keimanan serta supaya dosa-dosa yang pernah diperbuat selama satu tahun yang lalu dapat diampuni dan membuka lembaran tahun baru dengan aktivitas yang lebih baik.

Pengajian malam 1 suro ini merupakan simbol kebebasan yang diperoleh umat islam dari masa kejahiliyahan. Bulan Muharram atau bulan Suro merupakan bulan pertama dalam sistem kalender Islam. Bulan Muharram merupakan salah satu dari empat bulan yang dimuliakan Allah. Kata Muharram artinya "dilarang". Pada bulan ini dilarang untuk melakukan hal-hal seperti peperangan dan bentuk persengketaan lainnya.

\section{Pelepasan Luwur}

Pelepasan Luwur makam Sunan Kudus hanya dilakukan oleh orang-orang tertentu atau para Kyai sepuh dan tokoh masyarakat, pembukaan secara simbolis dilakukan di dalam makam Sunan Kudus kemudian diikuti dengan pembukaan atau pelepasan Luwur 
diluar dan sekitar makam Sunan Kudus oleh para pengurus YM3SK dan warga yang hadir dan dengan ikhlas membantu. Kain-kain Luwur atau mori tadi kemudian dibawa ke tajug untuk kemudian di lipat dan di tata rapi untuk kemudian disimpan dan di bagi pada waktu upacara puncak tanggal 10 suro nanti.

Luwur Maksud dari pembagian
tabarakan/ngalab adalah
barokah/mengambil berkah karena makam Sunan Kudus buka 24 jam untuk membaca $\mathrm{Al}$ quran sehingga insya allah kain mori itu akan menjadi perantara dalam memperoleh berkah atau rejeki. Makam Sunan Kudus sudah berusia sekitar 600 tahun sehingga langkah yang diambil untuk menjaga dan melestarikan makam Sunan Kudus ini, maka keluarlah kebijakan untuk menutup makam dan tidak memperkenankan setiap orang untuk masuk (Wawancara dengan Bapak Haji Nur Riza, Juru Kunci Makam Sunan Kudus. Selasa 7 Maret 2017).

4. Munadharah Masail Diniyah

Rangkaian acara Buka Luwur setelah pembukaan Luwur yaitu Munadharah Masail Diniyah merupakan suatu bentuk forum untuk belajar dan memperdalam ilmu-ilmu agama yang dihadiri oleh umum dan para Kyai. Acara ini dilaksanakan pada tanggal 4 Suro, acara ini dilaksanakan di serambi depan Masjid Menara Kudus. Acara ini mempunyai tujuan mulia yaitu belajar bersama tanpa membedakan tingkat usia, ilmu yang dimiliki dan senioritas. Dalam acara ini, bagi yang lebih mengerti akan memberi arahan dan petunjuk bagi siapa saja yang belum mengerti dan memahami persolan dalam ilmu agama. Namun nampaknya, sifat demokratis dan egaliter dalam acara ini belum berjalan sebagaimana mestinya karena unsur penghormatan terhadap yang lebih tua masih ada, terlebih lagi jika dikaitkan dengan proses pembelajaran di pesantren.

\section{Khataman Al Qur'an Bil Ghaib}

Khataman Al Qur'an bil Ghaib merupakan kegiatan mengaji Al Qur'an tanpa teks oleh para khafidz (hafal Al Qur'an diluar kepala). Sebelum khataman dimulai, terlebih dahulu diadakan pembukaan dan sedikit tausiah dari K. $\mathrm{H}$. Sya'roni Ahmadi. Dalam tausiah, beliau menjelaskan bahwa khataman Al Qur'an yang dilakukan merupakan rangkaian acara untuk menyemarakkan Buka Luwur Makam Sunan Kudus yang sudah dilakukan berkali-kali dan berulangulang serta menjadi kebiasaan dalam setiap acara Buka Luwur. K. H. Sya'roni Ahmadi menyatakan bahwa khataman yang dilakukan ini pahalanya dihadiahkan khusus kepada Kanjeng Sunan Kudus, dan bagi kita yang mengikutinya diharapkan mendapat barokah/tabarukan dari khataman yang dilakukan.

\section{Santunan Anak Yatim}

Bulan Suro merupakan bulannya anak yatim sehingga pada bulan ini umat Islam dianjurkan untuk menyayangi anak-anak yatim dengan cara mengelus-elus sebagian rambut kepala dan memberikan sedikit santunan sesuai kemampuan kita. Pahala yang diberikan Allah jika kita menyayangi anak yatim pada bulan suro yaitu sebanyak 
jumlah rambut yang dimiliki anak yatim yang kita sayangi tadi.

\section{Masak Bubur Asyuro}

Bubur asyuro ini merupakan simbol peringatan dan selamatan atas selamatnya Nabi Nuh A. S dari air bah yang melanda waktu itu. Bubur asyuro ini akan dibagi-bagikan kepada penduduk sekitar masjid, bubur ini dibagi dan ditempatkan dalam wadah yang disebut takir yang terbuat dari daun pisang.

\section{Pengajian Malam 10 Suro}

Pada pengajian ini peneliti sempat berbincang-bincang dengan seorang bapak yang berasal dari Ngaliyan Kota Semarang. Peneliti mencoba bertanya mengenai beberapa hal tentang kedatangan bapak tersebut ke acara pengajian dan Buka LuwurSunan Kudus dan diperoleh keterangan sebagai berikut:

Saya sudah lima tahun lebih menghadiri Buka Luwur Sunan Kudus, tiap malam jumat kliwon saya juga sering kesini untuk ziarah dan berdoa mohon barokah dari Sunan Kudus dan alhamdulillah saya mendapat berkah dengan lancarnya usaha dagang saya. Selain itu saya juga mendapatkan ketenangan hati dan pikiran setelah berziarah ke Sunan Kudus (Wawancara tanggal Kamis 9 Maret 2017).

\section{Pembagian Berkat Umum}

Antusias masyarakat terhadap Buka Luwur Sunan Kudus memang luar biasa. Banyaknya peziarah yang datang merupakan yang peneliti maksudkan, peziarah tidak hanya datang dari daerah Kudus saja, melainkan dari luar daerah juga banyak sekali yang datang. Para peziarah datang mengikuti Buka Luwur karena mengharapkan berkah dari nasi jangkrik goreng yang dibagikan.

Para peziarah rela antri dan berdesak-desakan untuk mendapat nasi jangkrik goreng. Umumnya nasi bungkus itu dibawa pulang, hanya sebagian kecil yang dimakan di tempat. Ada kepercayaan hingga kini di masyarakat, jika nasi yang diperoleh dari ritual Buka Luwur itu berkhasiat. Untuk pertanian, misalnya setelah nasi bungkus itu dikeringkan, lalu disebarkan ke tanaman, dipercaya akan memberikan kesuburan.

Buka Luwur Sunan Kudus merupakan bukti nyata dari kecintaan masyarakat Kudus kepada leluhurnya. Buka Luwur merupakan sebuah fenomena kepercayaan kejawen klasik yang masih ditemukan di jaman sekarang. Hal ini tidak dipungkiri karena pada waktu itu masyarakat Kudus merupakan masyarakat Jawa yang sangat patuh memegang adat-istiadat yang berlaku pada saat itu dan tentunya sampai sekarang masih dijaga keberadaan dan kelestariannya.

Ada tiga alasan masyarakat Kudus mengadakan Buka Luwur Sunan Kudus, yaitu: pertama, Buka Luwur merupakan wujud penghormatan masyarakat Kudus kepada leluhurnya yaitu Sunan Kudus yang telah berhasil membentuk pola kehidupan masyarakat Kudus yang religius. Kedua, Buka Luwur merupakan bentuk penghormatan masyarakat Kudus kepada Sunan Kudus sebagai seorang yang berkuasa dan menjadi junjungan masyarakat Kudus. Ketiga, Buka Luwur diadakan 
sebagai bentuk peringatan dan penghormatan terhadap Sunan Kudus yang telah wafat, namun tanggal wafatnya tidak diketahui secara pasti sehingga dipilih tanggal 10 Suro atau Muharram untuk memperingati haul Sunan Kudus.

Masyarakat pendukung Buka Luwur Sunan Kudus tentunya mempunyai maksud tersendiri mengapa dia berpartisipasi dalam pelaksanaan Buka Luwur Sunan Kudus. Beberapa maksud diharapkan dari masyarakat yang berhasil peneliti temukan antara lain mereka mengharapkan mendapat berkah atau ngalab barokah dari Sunan Kudus dengan memperbutkan sego jangkrik, mencari jodoh, memohon doa untuk kelancaran usaha, sekedar meramaikan acara dan lain-lain. Bagi beberapa pihak yang berkepentingan ganda Buka Luwur Sunan Kudus juga dijadikan sebagai arena bagi mereka untuk mewujudkan maksud tersebut. Dalam Buka Luwur ini juga ada rasa persatuan yang muncul dengan kuat dari sesama umat muslim terutama masyarakat Kudus dimana dengan suka rela mereka bersatu-padu untuk membantu pelaksanaan Buka Luwur Sunan Kudus dengan menyumbangkan apa yang mereka miliki.

Apa yang dilakukan masyarakat Kudus merupakan sebuah wujud adanya rasa persaudaraan sesama umat muslim atau dalam konsep Islam dikenal dengan Ukhuwah Islamiyah. Ukhuwah Islamiyah adalah keterikatan hati dan jiwa satu sama lain dengan ikatan aqidah islam atau persaudaraan sesama umat islam. Ukhuwah Islamiyah bukan saja mencirikan kualitas ketaatan seseorang terhadap ajaran Allah dan Rasul, tetapi sekaligus merupakan salah satu kekuatan perekat sosial untuk memperkokoh kebersamaan.

Pesan yang terkandung dalam Buka Luwur Sunan Kudus yaitu supaya orang-orang dapat mengikuti keteladanan Sunan Kudus dan mengingatkan agar orang-orang membiasakan diri untuk bersedekah. Buka Luwur Kudus Sunan mengandung makna dan simbol nilai-nilai luhur dan nilai edukatif yang tinggi yaitu: rasa toleransi kepada sesama, rasa saling tolongmenolong dan menghargai, melatih dan membiasakan diri bersedekah, selalu mendekatkan diri kepada Tuhan, mampu membina budi pekerti luhur dan mengekang perbuatan negatif serta mengingatkan agar orang-orang supaya beramalibadah yang baik untuk bekal kehidupan sesudah mati.

Pelajaran paling berharga dari Buka Luwur bagi masyarakat Kudus khususnya yaitu rekonstruksi memori historis terhadap identitas lokal. Masih hidup dan terus bertumbuhnya komunitas muslim yang hidup rukun berdampingan dengan pemeluk agama lain merupakan salah satu bukti nyata peninggalan sejarah kebudayaan dari Sunan Kudus sebagai seorang penyebar Islam di Pantai Utara Jawa. 


\section{Kerangka Model Implementasi Makna Dan Nilai Dalam Buka Luwur Makam Sunan Kudus untuk mewujudkan visi Kampus Kebudayaan}

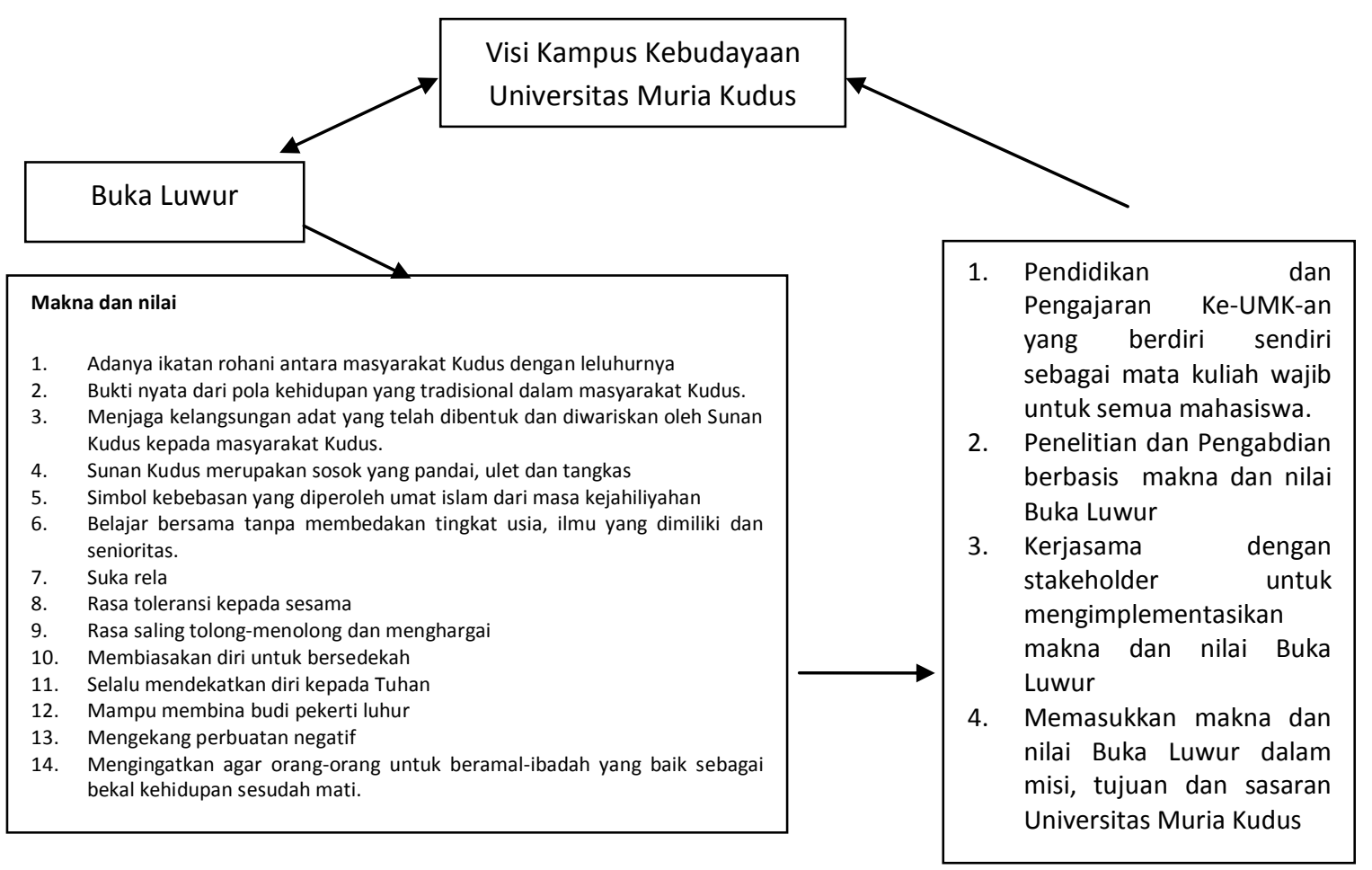

(Sumber: disarikan oleh Peneliti 2017).

Makna dan nilai yang tergali dari Buka Luwur sebagai salah satu budaya masyarakat Kudus menjadi tidak berarti manakala tidak diimplementasikan dalam kehidupan sehari-hari. Universitas Muria Kudus sebagai salah satu perguruan tinggi di Kudus yang lahir dan terinspirasi oleh sosok Sunan Kudus dan Sunan Muria memiliki kewajiban dan tanggung jawab moral untuk melestarikan makna dan nilai yang tergali.

Makna dan nilai Buka Luwur yang tergali sangat relevan dengan Universitas Muria Kudus yang memiliki visi menjadi "Kampus Kebudayaan" dengan ciri khas lulusan "Cerdas dan Santun". Melalui Tri Darma perguruan maka makna dan nilai Buka Luwur dapat diimplementasikan dalam setiap darma dalam upaya mewujudkan visi "Kampus Kebudayaan".

Kerangka model yang ditawarkan sebagai hasil penelitian perlu ditindaklanjuti oleh Universitas Muria Kudus sehingga visi menjadi "Kampus Kebudayaan" dapat tercapai dan lulusan "Cerdas dan Santun" berhasil dicapai. Ketercapaian visi dan keberhasilan lulusan memiliki ciri khas dapat terwujud ketika semua civitas akademika Universitas Muria Kudus mendukung dengan sepenuh hati apa yang ditawarkan oleh penelitian ini.

\section{SIMPULAN}

Buka Luwur Sunan Kudus merupakan bentuk rasa hormat masyarakat Kudus kepada Sunan

\section{4 | Jurnal Kredo}


Kudus yang telah berjasa membentuk pola kehidupan masyarakat Kudus yang religius. Buka Luwur Sunan Kudus bagi masyarakat Kudus mempunyai nilai sangat tinggi, yaitu meneladani nilai-nilai dari perjuangan para wali khususnya Sunan Kudus dalam hidup bermasyarakat.

Mengingat Buka Luwur Sunan Kudus memiliki makna dan nilai yang sangat tinggi dan luhur, saran yang dapat peneliti kemukakan sebagai berikut
1. Universitas Muria Kudus perlu menggali budaya lokal Kudus lebih lanjut untuk mendukung pencapaian visi Universitas Kebudayaan.

2. Buka Luwur Sunan yang penuh makna dan nilai perlu untuk diaplikasikan dalam pembelajaran melalui mata kuliah Ke-UMK-an, sehingga visi Universitas Kebudayaan tercapai.

\section{DAFTAR PUSTAKA}

Argarini, Masita. 2015. Persepsi Masyarakat Kudus Terhadap Simbol Visual Pada Tradisi Buka Luwur Sunan Kudus. Skripsi. Surakarta: Universitas Sebelas Maret.

Damami, Muhammad. 2001. Makna Agama dalam Masyarakat Jawa. Yogyakarta: Lesfi

Darmodiharjo, Darji, dkk. 1991. Santiaji Pancasila. Surabaya: Usana Offset Printing.

Daroeso, Bambang. 1986. Dasar dan Konsep Pendidikan Moral Pancasila. Semarang: Aneka Ilmu.

Djojomartono, Mulyono. 1991. Perubahan Kebudayaan dan Masyarakat Dalam Pembangunan. Semarang: IKIP Semarang Press.

Djajasudarma, T. Fatimah. 1993. Metode Linguistik: Ancangan Metode Penelitian dan Kajian. Bandung: Eresco.

Fuadi. Akhlis. 2013. Upacara Buka Luwur Makam Sunan Kudus Di Kabupaten Kudus. Skripsi. Semarang: Universitas Diponegoro.

Geertz, Clifford. 1989. Abangan, Santri, Priyayi Dalam Masyarakat Jawa. Jakarta: Pustaka Jaya.

Herusatoto, Budiono. 2003. Simbolisme dalam Budaya Jawa. Yogyakarta: Hanindita Graha Widya. 
Ismaya, Erik Aditia. 2008. Makna Simbolik Dibalik Upacara Buka Luwur Makam Sunan Kudus (Studi Kasus Di Desa Kauman Kecamatan Kota Kabupaten Kudus. Skripsi. Semarang: Universitas Negeri Semarang.

Ismaya, Erik Aditia. 2013. Guru Yang Cerdas dan Santun, Profil Guru Profesional dan Berkarakter Lulusan Universitas Muria Kudus. Makalah. Disampaikan dalam Seminar Nasional Peranan Guru Profesional Dan Berkarakter Dalam Pembangunan Sumber Daya Manusia di Era Global yang diselenggarakan oleh Program Studi Pendidikan Guru Sekolah Dasar Fakultas Keguruan dan Ilmu Pendidikan Universitas Muria Kudus. Sabtu, 30 Maret 2013.

Kaplan, David dan Robert A. Manners. 2002. Teori Budaya. Yogyakarta: Pustaka Pelajar.

Koentjaraningrat, 1981. Beberapa Pokok Antropologi Sosial. Jakarta: Dian Rakyat. 1987. Sejarah Teori Antropologi I. Jakarta: UI Press. 1990. Pengantar Ilmu Antropologi. Jakarta: Rineka Cipta.

Kristanto, Wahyu. 2008. Tradisi Buka Luwur Makam Sunan Kudus. Departemen Kebudayaan dan Pariwisata Direktorat Jenderal Sejarah dan Purbakala Balai Pelestarian Peninggalan Purbakala Jawa Tengah.

Kuswarno, Engkus. 2009. Fenomenologi. Bandung: Widya Padjajaran.

Moleong, Lexy. 2004. Metode Penelitian Kualitatif. Bandung: PT. Remaja Rosda Karya.

Ni'mah, Ulin. 2007. Tradisi Buka Luwur di Makam Sunan Kudus Kabupaten Kudus: Studi Tentang Pengelolaan Dana Umat Untuk Pengembangan Dakwah Islam. Skripsi. Semarang: Institut Agama Islam Negeri Walisongo.

Nindito, Stefanus. 2005. Fenomenologi Alfred Schutz: Studi tentang Konstruksi Makna dan Realitas dalam Ilmu Sosial. Jurnal Ilmu Komunikasi 2 (1), hlm: 79-94.

Nuha, Ulin. 2016. Tradisi Ritual Buka Luwur (Sebuah Media Nilai-nilai Islam dan Sosial Masyarakat Kudus). Jurnal SMaRT Studi Masyarakat, Religi dan Tradisi 02 (01), hlm. 55-65. Diperoleh dari Website Journal: http://blasemarang.kemenag.go.id/journal/index.php/smart (diunduh pada 06 Oktober 2016).

Nurhayati, Feby et al. 2007. Wali Sanga: Profil dan Warisannya. Yogyakarta: Pustaka Timur.

Pateda, Mansoer. 2001. Semantik Leksikal. Jakarta: Rineka Cipta.

Pemerintah Kabupaten Kudus. 2017. Kudus Dalam Angka 2016. Kudus: Badan Pusat Statistik Kabupaten Kudus.

56 | Jurnal Kredo

Vol. 1 No. 1 Oktober 2017 
Pusat Bahasa Departemen Pendidikan Nasional. 2008. Kamus Bahasa Indonesia. Jakarta: Pusat Bahasa.

Rachman, Maman. 2015. Lima Pendekatan Penelitian. Yogyakarta: Magnum Pustaka Utama.

Salam, Solichin. 1960. Sekitar Wali Songo. Kudus: Menara Kudus. 1986. Ja'far Shadiq (Sunan Kudus). Kudus: Menara Kudus.

Sastroatmodjo, Suryanto. 2006. Citra Diri Orang Jawa. Yogyakarta: Narasi.

Sudaryat, Yayat. 2009. Makna dalam Wacana. Bandung: Yrama Widya.

Sulaiman. 1992. Struktur Sosial dan Nilai Budaya Masyarakat. Yogyakarta: APD.

Suminto, Sayuti. 2000. Berkenalan Dengan Prosa Fiksi. Yogyakarta: Gama Media. 